\title{
BM] Global Health Resilient health systems for attaining universal health coverage
}

\begin{abstract}
Prosper Tumusiime (D) , ${ }^{1}$ Juliet Nabyonga-Orem (D) ,2 Humphrey Karamagi, ${ }^{1}$ Uta Lehmann, ${ }^{3}$ Tarcisse Elongo, ${ }^{1}$ Jean-Baptiste Nikiema, ${ }^{1}$ Grace Kabaniha, ${ }^{1}$ Joseph Okeibunor (1) ${ }^{1,4}$
\end{abstract}

To cite: Tumusiime $P$,

Nabyonga-Orem J, Karamagi $\mathrm{H}$, et al. Resilient health systems for attaining universal health coverage. BMJ Global Health 2019;4:e002006. doi:10.1136/ bmjgh-2019-002006

Received 18 September 2019 Accepted 18 September 2019

Check for updates

(c) Author(s) (or their employer(s)) 2019. Re-use permitted under CC BY-NC. No commercial re-use. See rights and permissions. Published by BMJ.

${ }^{1}$ Health Systems and Services Cluster, World Health Organization Regional Office for Africa, Brazzaville, Congo ${ }^{2}$ World Health Organization, Inter-Country Support Team for Eastern \& Southern Africa, Health systems and services cluster, Harare, Zimbabwe ${ }^{3}$ School of Public Health, University of the Western Cape, Cape Town, South Africa ${ }^{4}$ Department of Sociology/ Anthropology, University of Nigeria, Nsukka, Nigeria

Correspondence to Dr Prosper Tumusiime; tumusiimep@who.int
The Millennium Development Goals (MDGs) galvanised global-level, regional-level and country-level efforts to scale up health interventions and improve health outcomes for health-related MDGs. However, despite improvements in coverage and in the health status of the African people, there persist challenges, to which countries need to pay attention. The 2013-2016 Ebola virus disease (EVD) outbreak in West Africa revealed many weaknesses in the health system detection, preparedness and response systems of the three most affected countries (Liberia, Guinea and Sierra Leone). These pointed to major gaps in the implementation of Integrated Disease Surveillance and Response and the International Health Regulation (IHR) 2005, as well as the weakness of health systems overall. ${ }^{12}$

More importantly, it brought to the fore the importance of building resilient health systems that can withstand shocks and sustain provision of regular health services. Kieny and Dovlo underscored this point and asserted that '...we need to build systems that are grounded in primary healthcare principles and capable of responding to routine as well as unexpected challenges that might arise in the future.... ${ }^{3}$ In pursuant of this agenda, the WHO Regional Office for Africa developed a framework for 'Strengthening health systems for Universal Health Coverage (UHC) and the Sustainable Development Goals (SDGs) in Africa' which consolidates systems and services around a logical results chain with the desired impact as attainment of the SDG three goal. The framework further provides a menu of options that countries can choose from to strengthen their health system. ${ }^{4}$

The global-level and country-level commitments provide a favourable window for building resilient health systems; a quest that is arguably not new-but should we have waited to be reminded by an unfortunate event of the
EVD outbreak? Travis et al in 2004 did raise similar concerns regarding health systems weaknesses impeding progress towards health goals in the MDG era. ${ }^{5}$ In building a case for health system strengthening as a prerequisite to global progress, Frenk in $2010^{6}$ highlighted the need for a better understanding of health systems and the prevalent misconceptions, which view the health system as 'a black box (too complicated), as a black hole (too costly to fix), or as a laundry list (inventory-mere list of organisations)'. Perhaps this explains years of seeming neglect and fragmented approaches.

Articles in this supplement address these issues and provide clarity on concepts as well as practical options. For example, inasmuch as district health systems should anchor UHC, current weakness are rooted in the colonial past and Tumusiime $e t a l^{7}$ identified the required strategic shifts to strengthening the district health system. The shortage of health workers is among the major bottlenecks African countries need to address. In response to this, the WHO African Region developed a Road map for scaling up the health workforce, but progress has been mainly in developing strategies and plans. Afiriye $e t a l^{8}$ noted that a lot still needs to be done to primarily improve the quality of the human resource for health $(\mathrm{HRH})$ strategies and ensure coordinated and effective implementation.

Furthermore, in curbing the HRH crisis, Asamani et at proposed a regional approach to replace the current inefficient and compartmentalised approach in meeting the region's human resource requirements. Community health workers as service providers were a response to the HRH gaps and have played a role, but experiences are varied. This has prompted the need to review community health workers' programmes and Lehmann $e t a l^{10}$ provide lessons as well as key 
foundational elements of successful community health worker programmes.

Supportive supervision engenders an opportunity to strengthen health workers' skills, improve human resource management and improve quality of care. This is indeed an old practice, but it is yet to yield desired results. ${ }^{11}$ Avortri et al ${ }^{12}$ drew attention to the misunderstanding of the concept and its implementation. They provide a deeper understanding of supportive supervision and how re-organisation of the approach can contribute to improved performance. Access to essential medicines and commodities is vital for good health outcomes and is indeed one of the indicators under SDG 3 '3.b.3 Proportion of health facilities that have a core set of relevant essential medicines available and affordable on a sustainable basis'. Droti et al highlighted the dire situation in the 8 WHO African Region Member States assessed. They make a case for strengthening medicine supply systems and allocating adequate funding for medicines as critical to remedy the situation. ${ }^{13}$

UHC is a broad agenda and the public sector cannot go it alone. In this regard, we turn to the role of the private for-profit sector who are already significant players in health service provision. In embracing this potential resource, Nabyonga-Orem et al highlighted the caveats and caution us that there are prerequisites that must be in place. ${ }^{14} \mathrm{~A}$ large segment of the population in sub-Saharan Africa turns to the traditional sector when ill. Relatedly, advances in research on traditional medicines implore us to forge meaningful partnerships with the traditional medicine sector for better health outcomes. Kasilo et $a l^{15}$ trace advances in research, product development, integration of traditional medicines into health system, as well as regulatory practices for traditional health practitioners. They highlight important considerations necessary to maximise the potential of this sector for UHC.

The role of context-specific evidence in navigating the road to UHC cannot be overemphasised and in this regard national health research systems must be strengthened. As Nabyonga-Orem and Okeibunor ${ }^{16}$ argue, global and regional opportunities must be harnessed but in doing so, countries need to create an enabling environment.

The WHO in the Africa Region is committed to supporting Member States to build resilient health systems for UHC and health security. Provision of tools, guidelines, capacity building and strengthening collaboration with global and continental players to harness all available resources and political leverage are among the approaches to achieve these goals.

Contributors JNO and PT led the drafting of the editorial, J0 contributed significantly to the drafting of the editorial. All authors reviewed and approved the editorial.
Funding This study was funded by WHO Africa Regional Office.

Competing interests None declared.

Patient consent for publication Not required.

Provenance and peer review Not commissioned; internally peer reviewed.

Data availability statement № data are available.

Open access This is an open access article distributed in accordance with the Creative Commons Attribution Non Commercial (CC BY-NC 4.0) license, which permits others to distribute, remix, adapt, build upon this work non-commercially, and license their derivative works on different terms, provided the original work is properly cited, appropriate credit is given, any changes made indicated, and the use is non-commercial. See: http://creativecommons.org/licenses/by-nc/4.0/.

\section{ORCID iDs}

Prosper Tumusiime http://orcid.org/0000-0001-6899-824X

Juliet Nabyonga-Orem http://orcid.org/0000-0002-1061-8678

Joseph Okeibunor http://orcid.org/0000-0002-6696-8503

\section{REFERENCES}

1. WHO Africa Regional Office. Ebola virus disease epidemic in West Africa: update and lessons learnt. Brazzaville, Congo: WHO Africa Regional Office, 2014.

2. World Health Organization. The 2014 Ebola Virus Disease Outbreak: Lessons Learnt and Way Forward, Sixty-fifth session N'Djamena. N'Djamena, Republic of Chad, 2015.

3. Kieny MP, Dovlo D. Beyond Ebola: a new agenda for resilient health systems. The Lancet 2015;385:91-2.

4. WHO Regional Office for Africa. Leave no one behind: strengthening health systems for UHC and the SDGs in Africa, Licence: CC BY-NCSA 3.0 IGO. Brazzaville Congo, 2017.

5. Travis $\mathrm{P}$, Bennett $\mathrm{S}$, Haines $\mathrm{A}$, et al. Overcoming health-systems constraints to achieve the millennium development goals. The Lancet 2004;364:900-6.

6. Frenk J. The global health system: strengthening National health systems as the next step for global progress. PLoS Med 2010;7:e1000089.

7. Tumusiime $\mathrm{P}, \mathrm{Kwamie} \mathrm{A}$, Akogun $\mathrm{O}$, et al. Towards universal health coverage: reforming the neglected district health system in Africa. BMJ Global Health 2019;4:e01498.

8. Afriyie DO, Nyoni J, Ahmat A. The state of strategic plans for health workforce in Africa bmjgh. BMJ Global Health 2019;4:e001115.

9. Asamani J, Akogun O, Nyoni j, et al. Towards a regional strategy for resolving the human resources for health challenges in Africa. BMJ Global Health 2019;4:e001533.

10. Lehmann U, Twum-Danso NAY, Nyoni J. Achieving universal health coverage: the role of community health worker programs. $B M J$ Global Health 2019;4:e001046.

11. Bradley S, Kamwendo F, Masanja H, et al. District health managers' perceptions of supervision in Malawi and Tanzania. Hum Resour Health 2013;11:43.

12. Avortri SG, Nabukalu JB, Nabyonga-Orem J. Supportive supervision to improve service delivery in low-income countries: is there a lack of conceptual clarity or its time for a change in strategy? BMJ Global Health 2019;4:e001151.

13. Droti B, O'Neill K, Mathai M, et al. Poor availability of essential medicines for women and children threatens Africa's progress towards SDG 3. BMJ Global Health 2019;4:e001306.

14. Nabyonga-Orem J, Nabukalu JB, Okuonzi SA. Partnership with the private for-profit sector for attaining universal health coverage in sub-Saharan Africa -Opportunities and caveats. BMJ Global Health 2019;4:e001193.

15. Kasilo OMJ, Wambebe C, Nikiema J-B, et al. Towards universal health coverage: advancing the development and use of traditional medicines in Africa. BMJ Global Health 2019;4:e001517.

16. Nabyonga-Orem J, Okeibunor J. Towards universal health coverage: can National health research systems deliver contextualised evidence to guide progress in Africa? BMJ Global Health 2019;4:e001910. 